\title{
KLASIFIKASI KARAKTERISTIK DAMPAK INDUSTRI PADA KAWASAN Permukiman TerdampaK Industri di Cemani KabuPaten SUKOHARJO
}

\author{
Desita Putri Pradani, Murtanti Jani Rahayu, Rufia Andisetyana Putri \\ Program Studi Perencanaan Wilayah dan Kota, \\ Fakultas Teknik \\ Universitas Sebelas Maret, Surakarta \\ Email: desitaputri54@gmail.com
}

\begin{abstract}
Cemani Village/kelurahan Cemani is one of regions in Kecamatan Sukoharjo, which is one of the industrial area. as listed in Sukoharjo Regional Spatial Plan year 2014, Cemani village located around the huge industrial company such as Batik Keris compan,Dan Liris company, Konimex company, and Sobisco company. The problem in this research is how is the classification characteristics of industrial area and how it affected residential areas of Sukoharjo Cemani? The purpose of this study was to determine the classification of the characteristics of industrial impacts on residential areas that affected by industrial areea at Cemani Sukoharjo. The method used is the deductive research methods with quantitative research. Technique of analysis that used is descriptive analysis. This research conclusion is the impacts of the major industries in Sukoharjo Cemani settlement are: the emergence of the settlement of labor / industrial workers, the emergence of slum area, water pollution and flood the area. Cassification of this bad impacts of the industrial area to the physical environment can be perceived by people's settlement in 0-500 m>500m - Ikilometer, and>1 kilometer from the industrial area.
\end{abstract}

Keywords: Industrial Impact, Industrial Impact Classification, Industrial Settlement Areas

\section{PENDAHULUAN}

Sektor industri merupakan sektor potensial yang memiliki peranan penting dalam pembangunan ekonomi suatu negara, khususnya negara berkembang, oleh karena itu sektor-sektor industri kini mulai banyak didirikan di negara-negara berkembang, salah satunya di Indonesia. Menurut Peraturan Menteri Perindustrian Nomor35 tahun 2010 tentang pedoman teknis kawasan industri dinyatakan bahwa ada beberapa kriteria dalam penentuan lokasi kawasan industri, di antaranya adalah bahwasanya jarak terhadap pemukiman minimal 2 kilometer, kemudian peruntukan lahan, merupakan lahan non pertanian, non pemukiman dan non konservasi, tetapi pada kenyataaannya di kawasan industri Cemani banyak sekali pemukiman yang jaraknya sangat dekat yakni kurang dari 2 kilometer dengan kawasan industri bahkan industri tersebut dikelilingi oleh permukiman warga, selain itu lahan yang dijadikan kawasan industri pada awalnya adalah lahan pertanian sawah. Hal ini tentu akan membawakan dampak terhadap lingkungan sekitarnya.

Dampak negatif lebih mengarah pada lingkungan fisik, seperti adanya pencemaran dan limbah yang dihasilkan oleh industri yang akan berpengaruh terhadap kondisi udara, kondisi air dan kondisi tanah. Seperti halnya yang terjadi di kawasan industri Cemani yang terkena dampak industri seperti pencemaran di sekitar industri, kawasan kumuh di kelurahan Banaran dan Sanggrahan, menjadi kawasan rawan banjir yang hampir mencakup seluruh kawasan. Dampak yang ditimbulkan oleh kegiatan industri berbeda-beda dalam radius yang berbeda. Perbedaan karakteristik dampak yang ditimbulkan pada setiap wilayah tentu akan diperlukan penanganan yang berbeda pula, maka penulis ingin mengetahui bagaimana klasifikasi karakteristik dampak industri pada kawasan permukiman terdampak industri di Cemani Sukoharjo. 


\section{TINJAUAN PUSTAKA}

Tinjauan pustaka menjabarkan mengenai teori yang digunakan dan menjadi dasar dalam penelitian ini dimana teori yang digunakan adalah terkait dampak industri terhadap permukiman.

\subsection{Kawasan Industri}

Kawasan industri adalah suatu daerah yang didominasi oleh kegiatan industri yang mempunyai fasilitas kombinasi terdiri dari peralatan-peralatan pabrik (industrial plants), sarana penelitian dan laboratorium untuk pengembangan, bangunan perkantoran, bank, serta fasilitas sosial dan fasilitas umum (Dirdjojuwono, 2004).

Kawasan industri menurut Keputusan Presiden Nomor 53 tahun 1989 tentang kawasan industri, pasal 1 menyebutkan bahwa kawasan industri adalah kawasan tempat pemusatan kegiatan industri pengolahan yang dilengkapi dengan prasarana, sarana dan fasilitas penunjang lainnya yang disediakan dan dikelola oleh pihak perusahaan kawasan industri.

\subsection{Kawasan Permukiman Terdampak Industri}

Menurut Peraturan Menteri Perindustrian Nomor 35 tahun 2010, jarak minimal lokasi kegiatan industri terhadap permukiman adalah 2000 meter (2 kilometer). Jarak minimal tersebut dimaksudkan untuk menghindari dampak kumuh yang ditimbulkan oleh kegiatan industri yang menghasilkan limbah dan polutan terhadap lingkungan sekitarnya.

Menurut Aprillia (2014) jarak terdekat dampak pencemaran yang dirasakan masyarakat akibat kegiatan industri adalah 500 meter dari lokasi industri. Menurut Damayanti (2010) adanya perindustrian akan menimbulkan dampak pada kawasan lingkungan sekitarnya dengan radius 1 -2 kilometer dari kawasan.

\subsection{Dampak Industri}

Widjajanti (2005) mengatakan bahwa kegiatan industri akan menarik para pekerja untuk menetap disekitarnya dan pertumbuhan penduduk tersebut akan menyebabkan berkembangnya permukiman yang pola dan kualitas lingkungannya tidak dapat dilepaskan dari keberadaan industri tersebut, sebagai konsekuensinya, industri harus menyediakan permukiman yang diperuntukan bagi para pekerja/buruh. Hal ini juga diatur dalam Peraturan Menteri Perindustrian Nomor 35 tahun 2010 tentang Pedoman Teknis Pengembangan Kawasan Industri.

Pendapatan yang relatif minim menyebabkan para pekerja industri mencari alternatif tempat tinggal yang dekat dengan lokasi tempat bekerja atau mencari lokasi yang paling mudah dicapai dari jalan utama yang dilalui kendaraan angkutan umum atau kendaraan angkutan perusahaan apabila perusahaan tersebut penyediakan kendaraan angkutan bagi para pekerjanya. Umumnya bagi pekerja industri yang menjadi prioritas utama dalam pemilihan huniannya lebih terletak pada aspek fungsinya sebagai tempat melakukan aktivitas hidup sehari-hari selain bekerja, sedangkan untuk aspek kenyamanan tidak begitu diperhatikan. Pondokan adalah tempat tinggal sewa yang memiliki karakteristik bentuk bangunan yang nampak seadanya, ruang yang relatif kecil, terjadi pemanfaatan ruang yang seefisien mungkin, dan jumlah kamar-kamar pondokan terbatas (Widyawati, 1991 : 6-7).

Yusuf (2014) juga menyebutkan bahwa keberadaan industri menyebabkan permasalahan permukiman yakni munculnya kawasan kumuh serta masalah lingkungan seperti polusi udara berupa asap buangan pabrik, polusi air yang berupa limbah cair yang dibuang oleh pabrik, polusi suara yang dihasilkan oleh mesin produksi yang dapat membisingkan telinga warga di sekitar industri dan menyebabkan banjir karena kurangnya daerah resapan air yang sudah berubah fungsi menjadi daerah perindustrian.

Pembangunan industri dapat menyebabkan banjir karena kurangnya daerah resapan air, daerah-daerah hijau atau resapan air sudah berubah fungsi menjadi daerah perindustrian.

\section{METODE PENELITIAN}

Metode penelitian ini berisi ruang lingkup, metode analisis dan variabel penelitian yang digunakan dalam penelitian untuk mengetahui klasifikasi karakteristik dampak industri pada kawasan permukiman terdampak industri di Cemani Kabupaten Sukoharjo. 
Desita Putri, Murtanti Jani, Rufia Andisetyana, Klasifikasi Karakteristik...

\subsection{Ruang Lingkup}

Ruang lingkup wilayah penelitian ini diawali dengan mengidentifikasi industriindustri besar yang ada di kawasan Cemani, selanjutnya dihitung jarak 2 kilometer dari industri-industri besar tersebut, yang bisa dilihat pada Lampiran.

Ruang lingkup pembahasan penelitian ini meliputi deliniasi wilayah terdampak industri, yang nantinya akan diketahui identifikasi klasifikasi karakteristik dampak industri pada permukiman.

\subsection{Metode Analisis}

Pendekatan penelitian yang digunakan adalah pendekatan deduktif dimana penelitian dilakukan dengan membandingkan hasil penelitian dengan teori yang telah ada guna merumuskan variabel yang dijadikan pedoman untuk menjawab tujuan penelitian. Pendekatan ini merupakan pendekatan untuk menguji teori dimana nantinya akan diketahui klasifikasi karakteristik dampak industri pada kawasan permukiman terdampak industri di Cemani Sukoharjo. Teori berperan untuk memfokuskan sesuatu yang bersifat abstrak sehingga kemudian dapat dirumuskan hipotesis untuk diuji (Sugiyono, 2009).

Populasi yang akan dihitung dari penelitian ini adalah dari populasi kelurahan sekitar industri. Untuk menentukan sampel dari populasi digunakan perhitungan maupun acuan tabel yang dikembangkan para ahli. Penelitian ini akan mewawancarai warga di tiap kelurahan dalam ruang lingkup penelitian dan pihak pelaku industri.

Teknik analisis yang digunakan dalam penelitian ini menggunakan analisis Geospatial Information System dan analisis deskriptif. AnalisisGeospatial Information System dalam penelitian ini adalah untuk mengoverlay kawasan permukiman terdampak industri.

\subsection{Variabel Penelitian}

Variabel yang digunakan dalam penelitian ini dapat dilihat padaTabel 1. berikut ini.

Tabel 1.Variabel Penelitian

\begin{tabular}{|l|l|l|l|l|}
\hline $\begin{array}{l}\text { Permen } \\
\text { perin }\end{array}$ & $\begin{array}{l}\text { Widya } \\
\text { wati }\end{array}$ & $\begin{array}{l}\text { Widjaja } \\
\text { nti }\end{array}$ & $\begin{array}{l}\text { Yusuf } \\
\text { Nomor }\end{array}$ & $\begin{array}{l}\text { Variabel } \\
\text { Terpilih }\end{array}$ \\
$\begin{array}{l}\text { 35 } \\
\text { tahun }\end{array}$ & & 2005 & & \\
2010 & & & & \\
\hline
\end{tabular}

\begin{tabular}{|l|l|l|l|l|}
\hline $\begin{array}{l}\text { Adanya } \\
\text { permuki } \\
\text { man } \\
\text { buruh/p } \\
\text { ekerja }\end{array}$ & $\begin{array}{l}\text { Muncul } \\
\text { nya } \\
\text { pondoka } \\
\text { pekerja }\end{array}$ & Muncul & $\begin{array}{l}\text { Munc } \\
\text { ulnya } \\
\text { kawas } \\
\text { an } \\
\text { permuki } \\
\text { man } \\
\text { kumuh } \\
\text { humu }\end{array}$ & $\begin{array}{l}\text { Munculny } \\
\text { a kawasan } \\
\text { kumuh } \\
\text { an pekerja }\end{array}$ \\
\hline & & $\begin{array}{l}\text { Polusi } \\
\text { air, } \\
\text { udara } \\
\text { dan } \\
\text { suara }\end{array}$ & $\begin{array}{l}\text { Polusi air, } \\
\text { udara dan } \\
\text { suara }\end{array}$ \\
\hline & & Banjir & Banjir \\
\hline
\end{tabular}

Klasifikasi karakteristik dampak industri akan terbagi menjadi empat. Pertama adalah wilayah terdampak radius 0-500 meter. Kedua adalah adalah wilayah terdampak radius $>500$ 1 kilometer. Ketiga adalah wilayah terdampak radius $>1$ kilometer. Keempat adalah wilayah yang tidak terdampak industri. Kategori dari hasil perhitungan analisis.

\section{HASIL PENELITIAN}

Kawasan terdampak industri merupakan deliniasi wilayah penelitian yang nantinya akan di bagi dalam beberapa klasifikasi dampak indsutri. Kawasan terdampak industri didapat dari wilayah penelitian yang dioverlay dengan dampak industri yaitu kawasan permukiman perkerja industri, kawasan kumuh, kawasan terdampak polusi, kawasan banjir di sekitar kawasan industri.

\subsection{Kawasan Permukiman Pekerja Industri}

Menurut observasi dan wawancara yang dilakukan terdapat 4 perumahan yang dibangun oleh pihak industri di antaranya Perumahan Batik Keris, Perumahan Dan Liris, Perumahan Cemani Indah, dan Perumahan Sanggrahan yang dilengkapi fasilitas seperti masjid/mushola, lapangan olah raga, pos keamanan lingkungan, balai pertemuan dan pusat kesehatan masyarakat/klinik kesehatan. Terdapat pula beberapa kawasan permukiman non formal yang difungsikan sebagai pondokan/kos-kosan bagi para pekerja industri. Kos-kosan atau kontrakan buruh/pekerja industri ini umumnya dihuni oleh pekerja yang berpenghasilan rendahmenengah, umumnya adalah pegawai kontrak. 
Sebagian besar penghuni yang tinggal di rumah kontrakan dan kos-kosan merupakan karyawan dengan status kontrak. Sebagian besar karyawan yang statusnya masih kontrak memperoleh pendapatan sesuai dengan Upah Minimum Regional yaitu kurang lebih $\mathrm{Rp}$. 1.390 .000 setiap bulannya. Para buruh industri tersebut sebagian besar memilih kos-kosan dengan harga sewa yang rendah yakni sekitar Rp 200.000,- sampai dengan Rp 300.000,-, sedangkan yang tinggal di permukiman formal yang disediakan industri rata-rata penghuninya merupakan karyawan ahli atau karyawan tetap, adapula yang sudah pensiun namun masih tinggal di permukiman tersebut.

Kawasan permukiman pekerja industri berada pada 3 kelurahan yakni meliputi Kelurahan Banaran, Cemani dan Sanggrahan. Permukiman ini jaraknya sangat dekat yakni antara $0-1$ kilometer dari lokasi industri, bahkan beberapa perumahan ada yang letaknya berdempetan dengan industri.

\subsection{Kawasan Permukiman Kumuh}

Menurut Suranto dalam artikel Solopos (13/1/2015), kelurahan Banaran dan Cemani termasuk dalam kawasan permukiman kumuh kategori sedang. Permukiman kumuh yang ada dalam wilayah penelitian ini di antaranya berada di sekitar sungai yang pada dasarnya merupakan kawasan ilegal untuk permukiman, permukiman non formal yang difungsikan sebagai pondokan/kos-kosan buruh industri. Permukiman tersebut diketahui berdasarkan observasi langsung, artikel koran dan peta kawasan kumuh di Surakarta dan Sukoharjo.

Permukiman kumuh yang ada di wilayah penelitian ini meliputi Kelurahan Banaran, Keluarahan Cemani, Kelurahan Laweyan, Kelurahan Panularan dan Kelurahan Tipes. Sebagian besar penghuni permukiman kumuh ini adalah pegawai pabrik, pedagang, dan lainlainyang umumnya berpenghasilan rendah menengah yakni sekitar Rp 750.000,- sampai dengan 1.500.000,- tiap bulannya. Hunian di kawasan ini didominasi oleh bangunan yang masih kurang layak huni karena belum memiliki persyaratan sesuai standar kesehatan hunian.

\subsection{Dampak Polusi}

Dampak polusi pada kawasan sekitar industri inididapat dari wawancara penduduk, pihak industri, observasi lapangan dan artikel di web mengenai profil Pabrik Batik Keris, Pabrik Dan Liris, Pabrik Konimex dan Pabrik Sobisco. Menurut wawancara penduduk yang tinggal berdekatan dengan industri-industri tersebut, mereka tidak merasakan dampak polusi yang dihasilkan oleh industri. Kondisi sumber air bersih di permukiman warga mempunyai kualitas yang cukup baik, tidak berbau maupun berwarna. Untuk kondisi udara di sekitar permukiman pun dirasa penduduk masih baik-baik saja, begitu pula dengan polusi suara yang tidak dirasakan oleh warga.

Penanggulangan limbah cair, sejak awal pembangunan pabrik, pihak industri tak segan menginventasikan dana yang besar untuk membangun instalasi pengolahan limbah cair sesuai standar pemerintah. Industri Batik Keris dan Dan Liris menggunakan sistem water treatment dalam menanggulanagi limbah cair yang dihasilkan, sehingga hasil pengolahan limbah dapat dimanfaatkan kembali untuk proses produksi, bahkan sistem pengolahan limbah cair Konimex berhasil mendapat peringkat cukup baik dalam Penilaian Peringkat Kinerja Perusahaan Program Kali Bersih yang diselenggarakan oleh Badan Pengendalian mengenai Dampak Lingkungan, demikian pula untuk limbah bentuk lain, pihak industri memasang instalasi penyaringan debu serta sistem perendam kebisingan suara mesin, sedangkan untuk memeliharan kesegaran udara dilakukan melalui penghijauan lingkungan di kawasan pabrik.

Menurut survei lapangan, pembuangan limbah hasil pengolahan masih berwarna meskipun tidak berbau, akan tetapi zat pewarna yang terkandung apabila dibuang dalam jumlah yang besar akan mengganggu ekosistem lingkungan yang ada. Pembuangan limbah tersebut dialirkan ke saluran drainase yang ada di sekitar industri yang nantinya bermuara ke sungai di dekat industri yang berjarak sekitar kurang dari 500 meter. Hal ini dapat membahayakan lingkungan sekitar terutama untuk ekosistem air yang ada dalam jaringan tersebut.

\subsection{Kawasan Banjir}

Menurut warga, setiap terjadi hujan lebat selama kurun waktu yang lama, pasti akan terjadi banjir. Data kawasan banjir ini didapat dari melihat peta rawan banjir Kota Surakarta dan Kabupaten Sukoharjo. Menurut data yang 
Desita Putri, Murtanti Jani, Rufia Andisetyana, Klasifikasi Karakteristik....

diperoleh, kawasan terdampak banjir di wilayah penelitian meliputi Kelurahan Banaran, Kelurahan Cemani, Kelurahan Sanggrahan, Kelurahan Laweyan, Kelurahan Panularan, dan Kelurahan Tipes. Permukiman sekitar industri yang menjadi kawasan terdampak banjir dapat dilihat pada gambar berikut ini.

\subsection{Analisis Klasifikasi Karakteristik Dampak Industri pada Permukiman Terdampak Industri di Cemani Sukoharjo}

Wilayah terdampak industri dengan radius $0-500$ meter ini mencakup beberapa dampak industri yakni di antaranya: dampak polusi, adanya kawasan tempat tinggal pekerja/buruh industri, adanya permukiman kumuh, kawasan banjir.

Wilayah terdampak industri dengan radius >500 meter -1kilometer ini juga mencakup beberapa dampak industri yakni di antaranya: adanya kawasan tempat tinggal pekerja/buruh industri, adanya permukiman kumuh, kawasan banjir.

Wilayah terdampak industri dengan radius $>1$ kilometer ini mencakup beberapa dampak industri yakni di antaranya: adanya permukiman kumuh dan kawasan banjir.

Wilayah tidak terdampak industri ini jaraknya sekitar kurang lebih lebih dari 1,5-2 kilometer dari lokasi industri. Wilayah tidak terdampak ini sebagian besar adalah lahan hijau atau pertanian, dan yang sebelah utara dan timur itu merupakan wilayah perkotaan Kota Surakarta sehingga dampak industri terhadap permukiman di sana dirasa masyarakat tidak terlalu berpengaruh pada permukiman itu sendiri.

\section{KESIMPULAN}

Kesimpulan dari penelitian ini adalah bahwa dampak industri yang dirasakan masyarakat pada permukiman industri di Cemani Sukoharjo adalah sejauh kurang lebih 0 meter sampai dengan 1,5 kilometer dari lokasi industri.

Dampak yang ditimbulkan oleh industriindustri besar pada permukiman di Cemani
Sukoharjo, antara lain: munculnya permukiman buruh/pekerja industri, munculnya kawasan permukiman kumuh, polusi air dan kawasan banjir.

Dampak keberadaan kawasan industri terhadap lingkungan fisik dapat dirasakan langsung oleh masyarakat yang lingkungan tempat tinggalnya baik yang berjarak $0-500$ meter, $>500$ meter -1 kilometer, maupun $>1$ kilometer dari kawasan industri, hanya saja dampak yang dirasakan berbeda-beda, semakin jauh jarak permukiman dari lokasi industri maka akan semakin berkurang dampak industri yang ditimbulkan.

\section{REFERENSI}

Aprillia, Fittiara. 2014.Kajian Dampak Keberadaan Industri Pabrik Korindo Ariabima Sari Di Kelurahan Mendawai, Kabupaten Kotawaringin Barat. Undip

Damayanti, Rully. 2010. Pertumbuhan Fisik Kota Karena Pengaruh Industrialisasi, studi kasus kota Ahmedabad - India. Yogyakarta: UGM

Dirdjojuwono, Roestanto W. 2004. Kawasan Industri Indonesia - Sebuah Konsep Perencanaan dan Aplikasinya. Bogor: Wirausahamuda.

Peraturan Menteri Perindustrian Nomor 35 tahun 2010 tentang Pedoman Teknis Pengembangan Kawasan Industri

Sugiyono. 2009. Statistika Untuk Penelitian. Bandung : Alfabeta

Suranto. 2015. "Kelurahan Banaran dan Cemani Termasuk Dalam Kawasan Permukiman Kumuh Kategori Sedang. Solo Pos (13 Januari 2015)

Widjajanti. 2005. Kimia Fisika Lingkungan. Balai Teknik Kesehatan Lingkungan. Yogyakarta

Widyawati, M.Sp. 1991. Pertumbuhan Penduduk dan Pola Permukiman. Universitas Indonesia

Yusuf, Hadi S. 2014. Dampak Industri Terhadap Lingkungan Hidup. Jakarta 


\section{LAMPIRAN}

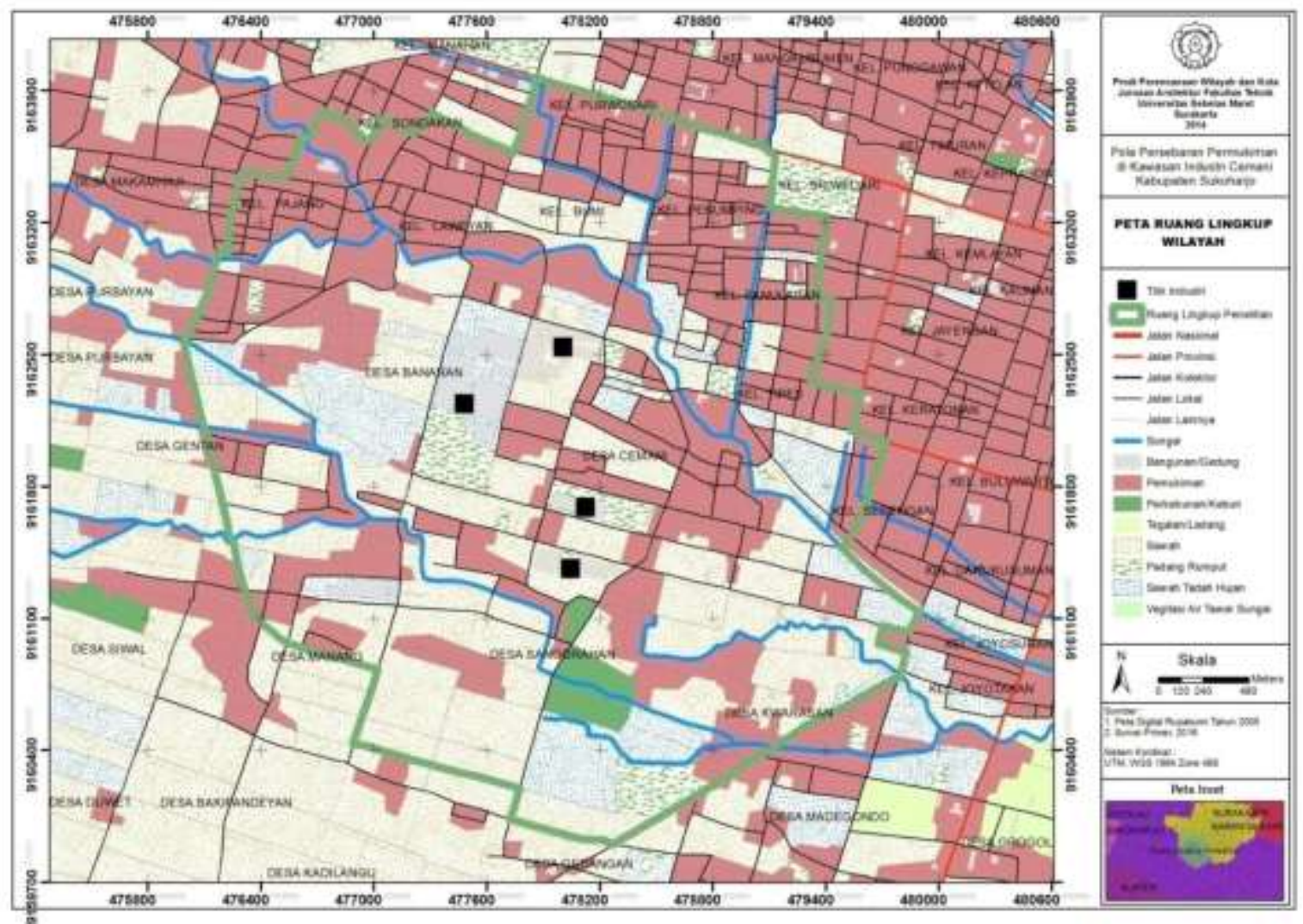

Gambar 1. Peta Ruang Lingkup Wilayah

(Peta Digital Rupabumi, 2005 dan Hasil Survey Primer, 2016) 